\title{
A NEW SPECIES OF METAPYROPPIA WOOLLEY, 1969 (ACARI, ORIBATIDA, PELOPPIIDAE) FROM NEPAL
}

\author{
Sergey G. Ermilov* \& Jochen Martens** \\ * Tyumen State University, Tyumen 625003, Russia \\ E-mail: ermilovacari@yandex.ru \\ urn:Isid:zoobank.org:author:89063E86-8DB6-4477-9F4E-6E0DA7E3BCBB \\ ** Johannes Gutenberg Universität, Mainz D-55099, Germany \\ E-mail: martens@uni-mainz.de \\ urn:Isid:zoobank.org:author:F01C78F1-5EBF-48E8-B37E-634DF00E0237
}

\begin{abstract}
A new species of oribatid mites of the family Peloppiidae, Metapyroppia gigantea $\mathbf{n}$. sp., is described from Nepal. The genus Metapyroppia is recorded for the first time from the Oriental region. Metapyroppia gigantea n. sp. differs from the type species, Metapyroppia doratosa Woolley, 1969, by the absence of notogastral setae $c_{2}$ and $c_{3}$, presence of pointed rostrum and the adanal lyrifissures distanced from the anal plates. The morphology of gnathosoma and legs are presented in detail for the first time for any member of this genus.
\end{abstract}

urn:Isid:zoobank.org:pub:EEE741F4-4C86-4625-B3FD-48E1DDA1D2D3

Key words: oribatid mite; Metapyroppia; new species; Nepal.

RESUMEN

Nueva especie de Metapyroppia Woolley, 1969 (Acari, Oribatida, Peloppiidae) del Nepal

Se describe una nueva especie de ácaro oribátido de la familia Peloppiidae, Metapyroppia gigantea n. sp., procedente de Nepal. Es la primera cita del género Metapyroppia en la región Oriental. Metapyroppia gigantea n. sp. se diferencia de la especie tipo, Metapyroppia doratosa Woolley, 1969, por la ausencia de las setas notogastrales $C_{2}$ y $C_{3}$, la presencia de un rostro puntiagudo y las lirifisuras adanales separadas de las placas anales. Por vez primera se describe detalladamente la morfología del gnathosoma y las patas en un miembro de este género.

Palabras clave: ácaros oribátidos; Metapyroppia; nueva especie; Nepal.

Recibido/Received: 31/08/2013; Aceptado/Accepted: 26/02/2014; Publicado en línea/Published online: 22/08/2014

Como citar este artículo/Citation: Ermilov, S. G. \& Martens, J., 2014. A new species of Metapyroppia Woolley, 1969 (Acari, Oribatida, Peloppiidae) from Nepal. Grael/sia, 70(1): e003. http://dx.doi.org/10.3989/graellsia.2014.v70.101.

Copyright: (C) 2014 SAM y CSIC. Salvo indicación contraria, todos los contenidos de la edición electrónica de Grael/sia se distribuyen bajo licencia de uso y distribución Creative Commons Reconocimiento no Comercial 3.0. España (cc-by-nc).

\section{Introduction}

Metapyroppia (Acari, Oribatida, Peloppiidae) is a monotypic oribatid mite genus that was proposed by Woolley (1969) with Metapyroppia doratosa Woolley, 1969 as type species. At present, this genus is known only from the Nearctic region. Hence, it is recorded for the first time in Nepal and the Oriental region.
The primary purpose of this paper is to describe and illustrate the second representative of Metapyroppia under the name $M$. gigantea $\mathbf{n}$. sp. We present in detail the morphology of the gnathosoma and legs, the first such data for any member of this genus.

Generic characters of Metapyroppia were very briefly proposed by Woolley (1969) and summarized by J. Balogh \& P. Balogh (1992). The secondary purpose of this paper is to present a new generic diagnosis. 


\section{Material and methods}

All specimens of Metapyroppia gigantea n. sp. were studied in lactic acid, mounted in temporary cavity slides for the duration of the study, and then stored in $70 \%$ ethanol in vials. Body measurements are presented in micrometers. The body length was measured in lateral view, from the tip of the rostrum to the posterior edge of the ventral plate. Notogastral width refers to the maximum width in dorsal aspect. Lengths of body setae were measured in lateral aspect. Formula for leg setation is given in parentheses according to the sequence trochanter-femur-genu-tibia-tarsus (famulus included). Formula for leg solenidia is given in square brackets according to the sequence genu-tibiatarsus. Terminology used in this paper mostly follows that of Norton \& Behan-Pelletier (2009).

\section{Systematics}

Genus Metapyroppia Woolley, 1969: 137

urn:1sid:zoobank.org:act:87391F87-5D20-4CE3-AED297F236F323A3

TYPE SPECIES: Metapyroppia doratosa Woolley, 1969

NeW Generic Diagnosis. Peloppiidae (Norton \& Behan-Pelletier, 2009) with the following combination of characters: lamellae long, clearly separated, slightly converging, with distinct, short cusps; translamella rudimental, represented only by short parts near to lamellae; bothridial setae with long stalk and lanceolate head; notogastral setae (or their alveoli) $c_{1}$ and $c_{2}$ located in humeral position, close to each other; posterior part of notogaster with two pairs of setae $\left(p_{1}, p_{2}\right)$; alveoli of dorsal notogastral setae (la, lm, $\left.l p, h_{1}, h_{2}\right)$ located in two rows dorso-laterally; chelicerae chelate-dentate; sejugal apodemes fused medially, located anteriorly to genital plates; epimeral setal formula: 3-1-3-3; adanal setae $a d_{1}$ and $a d_{2}$ located in postanal position; legs heterotridactylous.

Metapyroppia gigantea n. sp. (Figs. 1-20)

urn:1sid:zoobank.org:act:04686454-6897-4B7D-8AB 1 A36272E8AF45

MATERIAL: Holotype female and eight paratypes (six females, two males) were collected by J. Martens and A. Ausobsky from Nepal: Mustang District, Purano Marpha above the village of Marpha, easteren Dhaulagiri massif, 3200-3600 m a.s.l., forest (prevailed Pinus wallichiana, Cupressus torulosa, Abies spectabilis) slightly north of the Himalayan main range, soil litter, 22.IV.1980.

The holotype and one paratype are deposited in the collection of the Senckenberg Institution, Frankfurt, Germany; two paratypes are deposited in the collection of the Siberian Zoological Museum, Novosibirsk, Russia; five paratypes are deposited in the collection of the Tyumen State University Museum of Zoology, Tyumen, Russia.

Diagnosis. Body size 996-1112×730-846. Body surface microtuberculate. Rostrum weakly pointed.
Rostral, lamellar and interlamellar setae long, barbed. Bothridial setae lanceolate. Notogastral setae (except $p_{1}$ and $p_{2}$ ) represented by alveoli. Pedotecta I with dorsal tooth. Anogenital setae of medium size, barbed. Adanal lyrifissures iad removed from the anal plates.

Description. Measurements. Body length 1095 (holotype, female), 996-1112 (eight paratypes: six females and two males); body width 813 (holotype), 730-846 (eight paratypes).

Integument. Body color light brown to brown. Body surface with dense, small rounded (diameter up to 4) or elongate (length up to 8) tubercles, forming a weakly visible polygonal network. Pedotecta II (Pd II) with reticulate pattern (length of cells up to 20).

Prodorsum. Rostrum pointed; rostral tooth $(t)$ small, weakly developed. Lateral carinae (car) distinct. Lamellar cusps truncate. Thin, poorly visible, longitudinal ridge $(r)$ located anteriorly to lamellae. Rostral (ro, 110-118) and lamellar (le, 151-164) setae setiform, acuminate, barbed; rostral setae inserted on small tubercles, lamellar setae - on lamellar cusps. Interlamellar setae (in, 127-139) thickened, tapered, straight, barbed. Bothridial setae (ss, 127-131) well developed, head slightly barbed. Exobothridial setae (ex, 53-57) setiform, thin, barbed. Tutoria $(t u)$ long, simple.

Notogaster. Anterior margin medially weakly convex. Two pairs of notogastral setae $\left(p_{1}, p_{2}, 49-65\right)$ setiform, barbed; other setae $\left(c_{1}, c_{2}, c_{3}, l a, l m, l p, h_{1}\right.$, $\left.h_{2}, h_{3}\right)$ represented by alveoli. Opisthonotal gland openings ( $g l a)$ small, located laterally to alveoli of notogastral setae $h_{3}$. Lyrifissures $i a, i m$, ih, ip and ips short, distinct.

Gnathosoma. Subcapitulum longer than width (221$225 \times 188-196)$. Three pairs of subcapitular setae setiform, slightly barbed; $h$ (65-77) longer than $m$ (57-65) and $a$ (49-57). Two pairs of adoral setae $\left(\right.$ or $_{1}$, or $\left._{2}\right)$ setiform, smooth, bent in median part. Palp (123-127) with

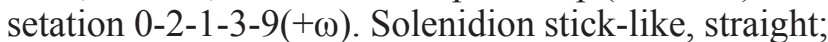
its distal part attached to the basal part of eupathidium $(\mathrm{acm})$. Chelicera (233-246) with two long, setiform, barbed cheliceral setae; cha (69-73) longer than chb (53-57). Trägårdh's organ ( $\mathrm{Tg}$ ) elongate conical.

Epimeral and lateral podosomal regions. Apodemes 1, 2 and sejugal apodemes distinct. Sejugal apodemes fused medially. Sternal longitudinal border present. Apodemes 3 invisible; apodemes 4 represented by shallow furrow, connected to lateral sides of genital plates. Epimeral setae setiform, thin, barbed; $1 b, 1 c$, $3 b, 3 c, 4 c$ (65-77) longer than $1 a, 2 a, 3 a, 4 a, 4 b$ (45$53)$. Setae $3 c$ inserted on pedotecta II ( $\mathrm{Pd}$ II). Pedotecta I large, with dorsal tooth $(p t)$; pedotecta II of medium size, scale-like. Discidia (dis) triangular.

Anogenital region. Six pairs of genital $\left(g_{1}-g_{6}\right)$, one pair of aggenital (ag), two pairs of anal ( $\left.a n_{1}, a n_{2}\right)$ and three pairs of adanal $\left(a d_{1}-a d_{3}\right)$ setae similar in length (41-53), setiform, straight, barbed. Genital plates shorter than anal plates; distance between genital and anal apertures is equal to half the length 

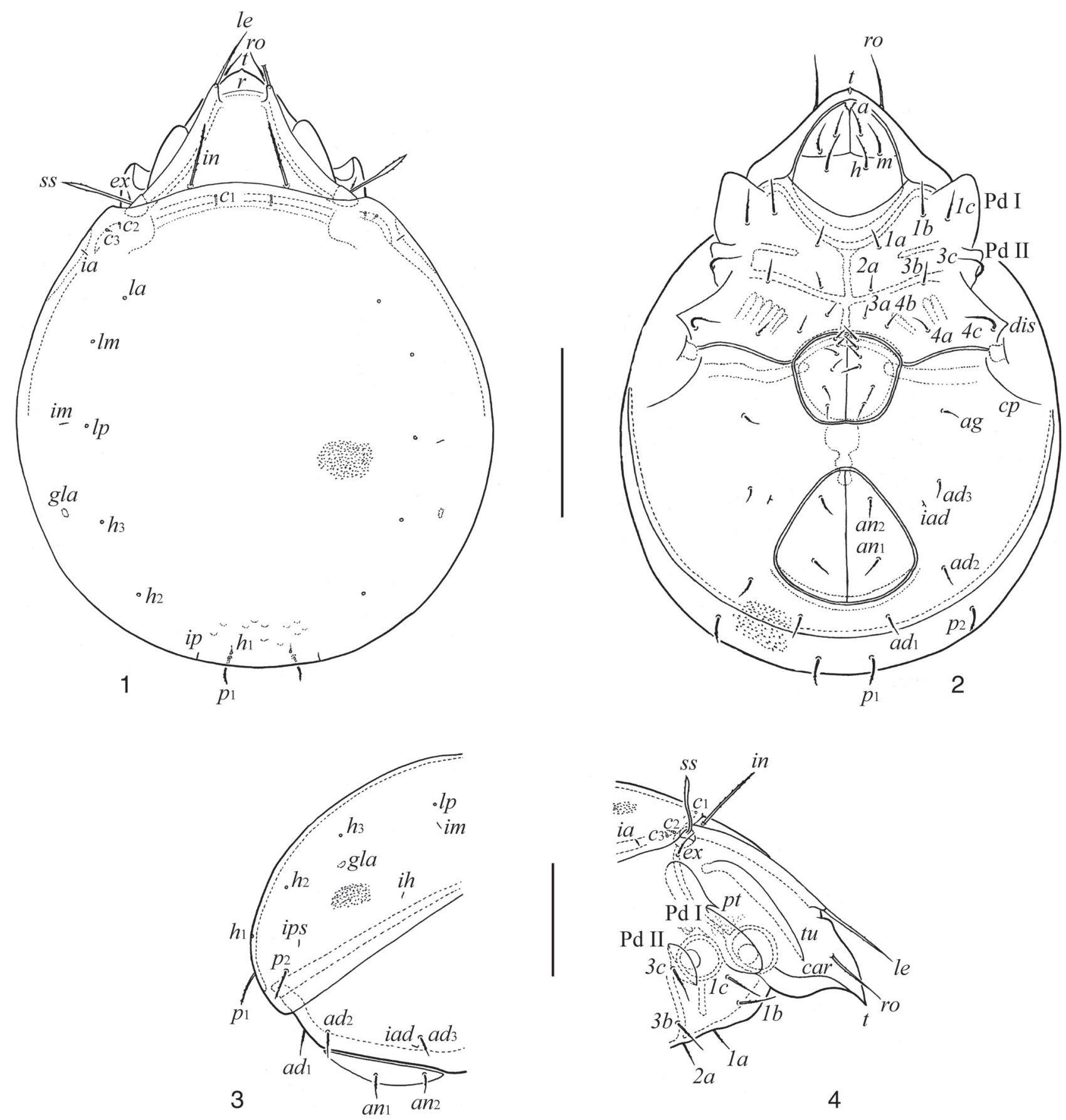

4

Figs. 1-4.- Metapyroppia gigantea n. sp. 1) Dorsal view, 2) ventral view (legs not illustrated), 3) lateral view of posterior part of notogaster, 4) lateral view of prodorsum and anterior part of notogaster (gnathosoma not illustrated). Scale bars $(1,2) 300 \mu \mathrm{m}$, $(3,4) 200 \mu \mathrm{m}$.

Figs. 1-4.- Metapyroppia gigantea n. sp. 1) Vista dorsal, 2) vista ventral (patas no ilustradas), 3) vista lateral de la región posterior del notogáster, 4) vista lateral del prodorso y la región anterior del notogáster (gnatosoma no ilustrado). Escalas: $(1,2) 300 \mu \mathrm{m}$, $(3,4) 200 \mu \mathrm{m}$.

of a genital plate. Lyrifissures iad located in paraanal position, clearly removed from the anal plates.

Legs. Median claw slightly thicker than lateral claws; all claws serrate dorsally. Formulae of leg setation and solenidia: I (1-5-3-4-20) [1-2-2], II (1-5-3-4-16) [1-12], III (2-3-2-3-15) [1-1-0], IV (2-2-3-3-12) [0-1-0]; homology of setae and solenidia indicated in Table 1 Setae setiform, barbed (except smooth $p$ ). Famulus $(e)$ setiform, blunt-ended, inserted between solenidia $\omega_{1}$ and $\omega_{2}$. All solenidia setiform, with swollen basal part.

EтYMology. The specific name "gigantea" is an adjective and refers to the large body size. 

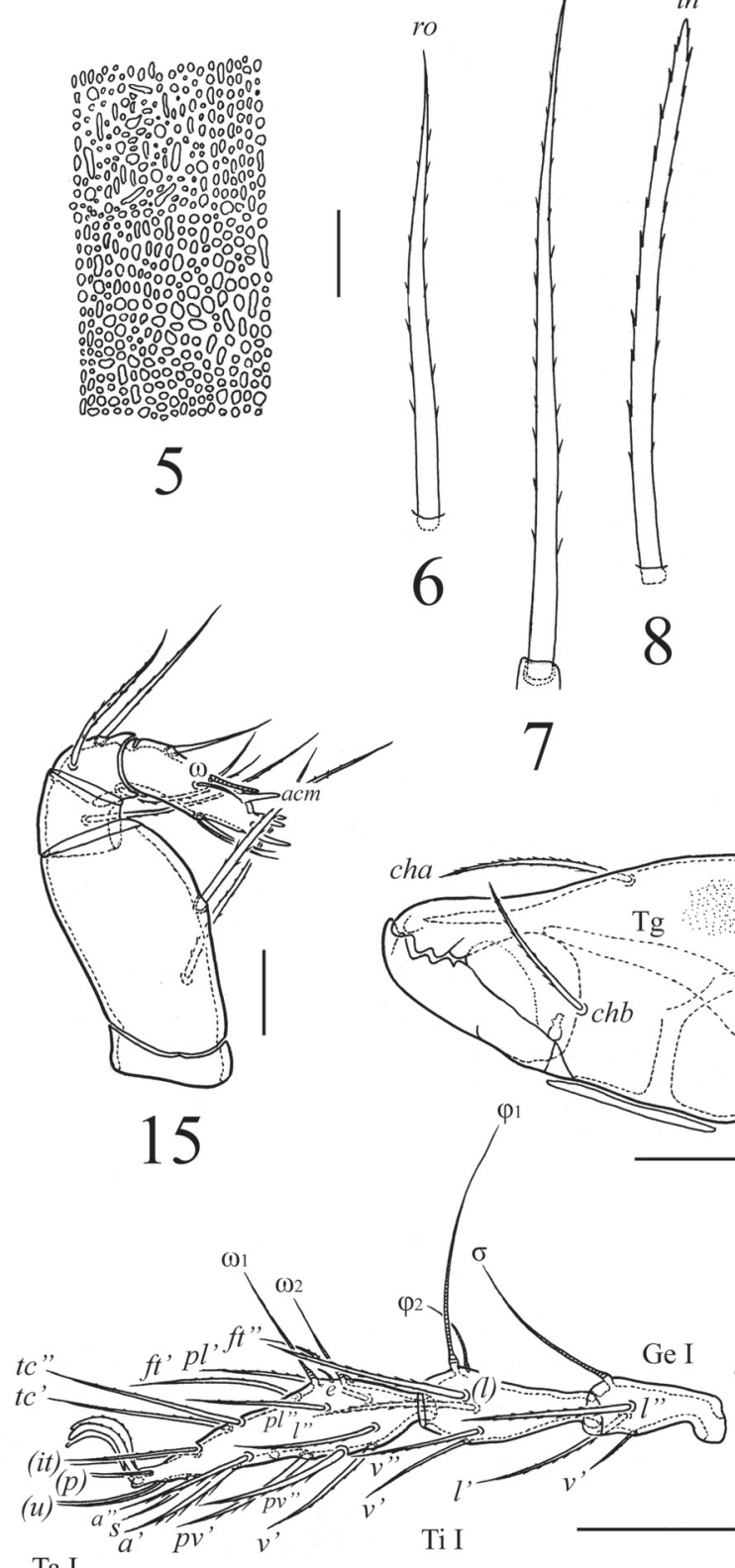

Ta I
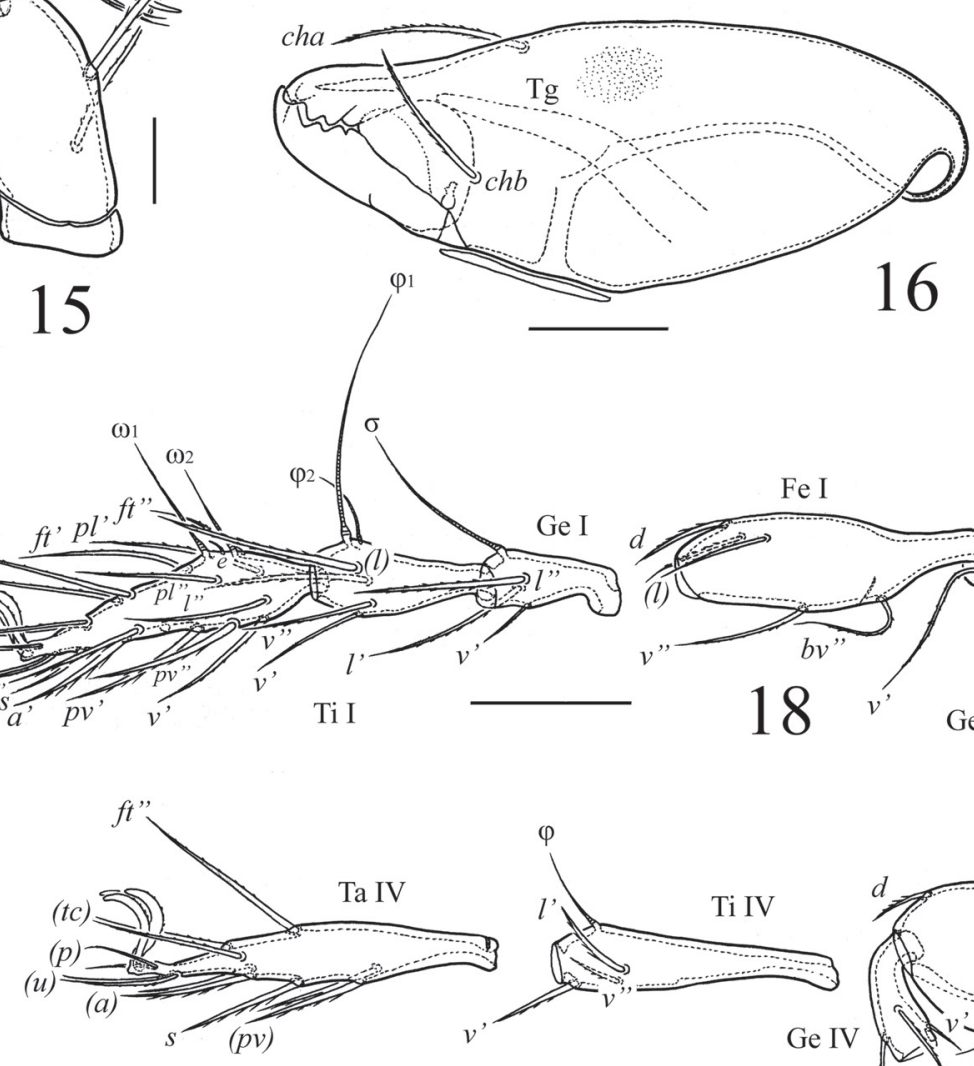

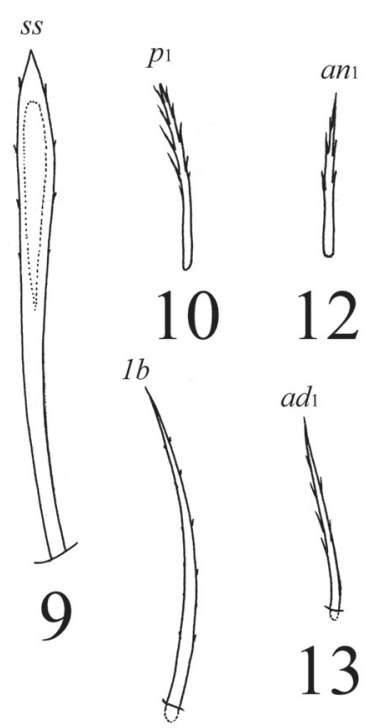

11

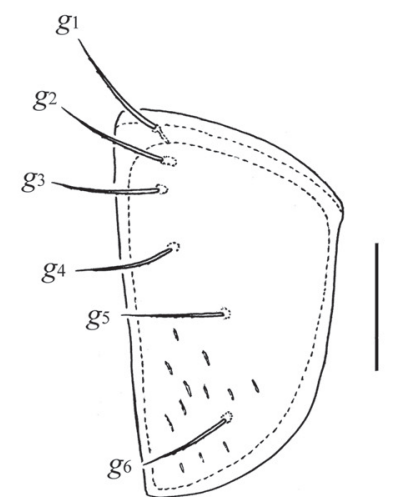

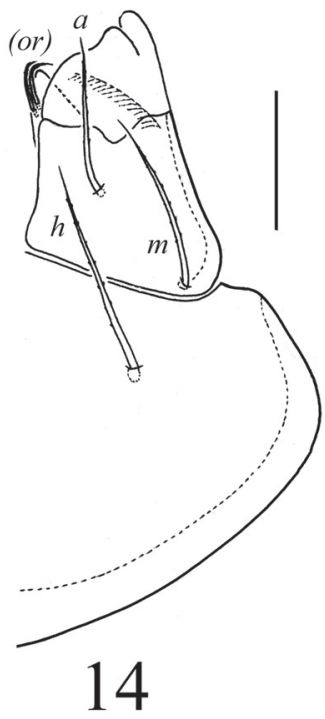

17
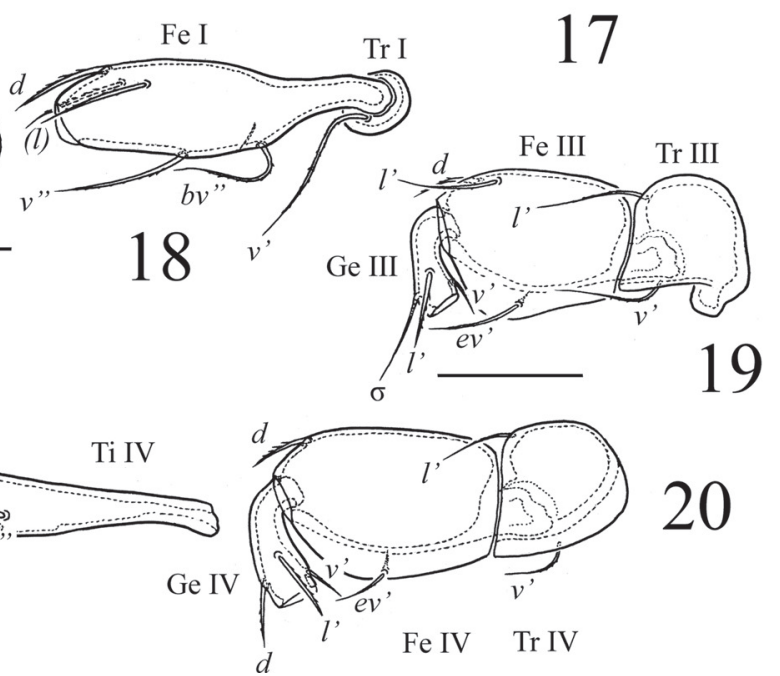

20

Figs. 5-20.- Metapyroppia gigantea n. sp. 5) Tubercles on posterior part of notogaster, 6) rostral seta, 7) lamellar seta, 8) interlamellar seta, 9) sensillus, 10) notogastral seta $p_{1}, 11$ ) epimeral seta $1 \mathrm{~b}, 12$ ) anal seta $a n_{1}, 13$ ) adanal seta $\left.a d_{1}, 14\right)$ subcapitulum, left half, ventral view, 15) palp, 16) chelicera, 17) genital plate, left, 18) leg I, left, antiaxial view, 19) trochanter, femur, genu of leg III, right, antiaxial view, 20) leg IV, right, antiaxial view. Scale bars $(5-13,15) 20 \mu \mathrm{m},(14,16,17) 50 \mu \mathrm{m},(18-20) 100 \mu \mathrm{m}$.

Figs. 5-20.- Metapyroppia gigantea n. sp. 5) Tubérculos de la región posterior del notogáster, 6) seta rostral, 7) seta lamelar, 8) seta interlamelar, 9) sensilo, 10) seta notogastral $p_{1}, 11$ ) seta epimeral $\left.1 b, 12\right)$ seta anal an 1,13 ) seta adanal ad $d_{1}$, 14) vista ventral de la mitad izquierda del subcapitulum, 15) palpo, 16) quelícero, 17) placa genital izquierda, 18) pata I izquierda, vista antiaxial, 19) trocánter, fémur y genu de la pata III derecha, vista antiaxial, 20) pata IV derecha, vista antiaxial. Escalas: $(5-13,15) 20 \mu \mathrm{m}$, $(14,16,17) 50 \mu \mathrm{m},(18-20) 100 \mu \mathrm{m}$. 
Table 1.- Leg setation and solenidia of Metapyroppia gigantea n. sp. Roman letters refer to normal setae (e-famulus), Greek letters refer to solenidia. One apostrophe (') marks setae on anterior and double apostrophe (") setae on posterior side of the given leg segment. Parentheses refer to a pair of setae.

Tabla 1.- Quetotaxia de las patas y solenidios de Metapyroppia gigantea n. sp. Las letras romanas se refieren a las setas normales (e-famulus) y las griegas a los solenidios. El apóstrofo (') señala las setas de la cara anterior el el doble apóstrofo (") las de la cara posterior de cada segmento de las patas. Los paréntesis indican pares de setas.

\begin{tabular}{lcllll}
\hline Leg & Trochanter & \multicolumn{1}{c}{ Femur } & Genu & \multicolumn{1}{c}{ Tibia } & \multicolumn{1}{c}{ Tarsus } \\
\hline I & $v^{\prime}$ & $d,(l), b v^{\prime \prime}, v^{\prime \prime}$ & $(l), v^{\prime}, \sigma$ & $(l),(v), \varphi_{1}, \varphi_{2}$ & $(f t),(t c),(i t),(p),(u),(a), s,(p v), v^{\prime},(p l), l^{\prime \prime}, e, \omega_{1}, \omega_{2}$ \\
II & $v^{\prime}$ & $d,(l), b v^{\prime \prime}, v^{\prime \prime}$ & $(l), v^{\prime}, \sigma$ & $(l),(v), \varphi$ & $(f t),(t c),(i t),(p),(u),(a), s,(p v), l^{\prime \prime}, \omega$ \\
III & $l^{\prime}, v^{\prime}$ & $d, l^{\prime}, e v^{\prime}$ & $l^{\prime}, v^{\prime}, \sigma$ & $l^{\prime},(v), \varphi$ & $(f t),(t c),(i t),(p),(u),(a), s,(p v)$ \\
IV & $l^{\prime}, v^{\prime}$ & $d, e v^{\prime}$ & $d, l^{\prime}, v^{\prime}$ & $l^{\prime},(v), \varphi$ & $f t^{\prime \prime},(t c),(p),(u),(a), s,(p v)$ \\
\hline
\end{tabular}

Remarks. Metapyroppia gigantea $\mathbf{n}$. sp. differs from the type species, Metapyroppia doratosa Woolley, 1969, from U.S.A. (see Woolley, 1969) by the absence (represented by alveoli) of notogastral setae $c_{2}$ and $c_{3}$ (versus developed in $M$. doratosa), weakly pointed rostrum (versus widely rounded in $M$. doratosa) and the adanal lyrifissures removed from the anal plates (versus located close to the anal plates in $M$. doratosa).

Also, Metapyroppia gigantea n. sp. is similar morphologically to Pseudoceratoppia microsetosa Hammer, 1967 from New Zealand (see Hammer, 1967), but it differs from the latter by the presence of two pairs of posterior notogastral setae (versus three pairs in P. microsetosa) and complete sejugal apodeme (versus not complete in $P$. microsetosa).

\section{Acknowledgements}

We cordially thank Prof. Dr. Luis S. Subías (Universidad Complutense de Madrid, Madrid, Spain) and an anonymous reviewer for the valuable comments. J. Martens thanks
A. Ausobsky for helpful companionship during the 1980 Nepal expedition, and, in addition, he thanks the Feldbausch Foundation and the Wagner Foundation at Fachbereich Biologie of Mainz University for many annual grants over the years to carry out field work in Asia.

\section{References}

Balogh, J. \& Balogh, P., 1992. The oribatid mites genera of the world. Vol. 1. Hungarian National Museum Press. Budapest. 263 pp.

Hammer, M., 1967. Investigations on the oribatid fauna of New Zealand. Part II. Det Kongelige Danske Videnskabernes Selskab Biologiske Skrifter, 15(4): 1-60.

Norton, R. A. \& Behan-Pelletier, V. M., 2009. Oribatida. In: G. W. Krantz \& D. E. Walter (eds.). A Manual of Acarology. Texas University Press. Lubbock: 430-564.

Woolley, T. A., 1969. A new genus and species of oribatid mite (Acari: Liacaroidea, Metrioppiidae). Great Basin Naturalist, 29(3): 137-139. 